Jurnal Keperawatan Silampari

Volume 3, Nomor 2, Juni 2020

e-ISSN: 2581-1975

p-ISSN: 2597-7482

DOI: https://doi.org/10.31539/jks.v3i2.1198

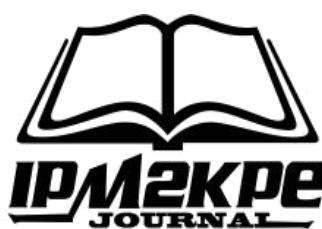

\title{
APLIKASI STANDAR PROSES KEPERAWATAN: DIAGNOSIS, OUTCOME, DAN INTERVENSI PADA ASUHAN KEPERAWATAN
}

\author{
Dheni Koerniawan ${ }^{1}$, Novita Elisabeth Daeli $^{2}$, Srimiyati $^{3}$ \\ Univeristas Katolik Musi Charitas ${ }^{1,2,3}$ \\ novita_daeli@ukmc.ac.id ${ }^{2}$
}

\begin{abstract}
ABSTRAK
Penelitian ini bertujuan untuk melihat kualitas dokumentasi asuhan keperawatan di RS Myria Palembang. Survei analitik digunakan untuk memperoleh gambaran dari dokumentasi keperawatan sebagai data sekunder. Dokumen asuhan keperawatan yang digunakan sebanyak 105 dokumen secara cluster sampling dan diukur menggunakan instrumen $Q-D I O$, serta dianalisis secara deskriptif. Hasil penelitian menunjukkan sebagian besar memiliki kualitas sedang pada seluruh dimensi, yaitu diagnosis sebagai proses sebanyak 70 dokumen (67\%), diagnosis sebagai produk sebanyak 56 dokumen (53\%), intervensi sebanyak 66 dokumen (63\%), dan luaran keperawatan sebanyak 67 dokumen $(64 \%)$. Simpulan pada penelitian ini menunjukkan bahwa $67 \%$ dokumen memiliki kualitas sedang pada dimensi diagnosis sebagai proses, 53\% dokumen memiliki kualitas sedang pada dimensi diagnosis sebagai produk, 63\% dokumen memiliki kualitas sedang pada dimensi intervensi, dan 64\% dokumen memiliki kualitas sedang pada dimensi luaran keperawatan. Hasil dari proses keperawatan yang telah didapatkan dalam penelitian ini menggambarkan perubahan atau peningkatan perbaikan gejala yang memiliki kualitas sedang untuk berintegrasi dengan prose keperawatan.
\end{abstract}

Kata Kunci: Diagnosis, Dokumentasi, Intervensi, Luaran

\begin{abstract}
This study aims to look at the quality of nursing care documentation at Myria Hospital Palembang. Analytic surveys are used to obtain an overview of nursing documentation as secondary data. Nursing care documents used were 105 documents by cluster sampling and measured using Q-DIO instruments, and analyzed descriptively. The results showed most of the medium quality in all dimensions, namely diagnosis as a process of 70 documents (67\%), diagnosis as a product as many as 56 documents (53\%), intervention as many as 66 documents (63\%), and nursing outcomes as many as 67 documents (64\%). The conclusions in this study indicate that $67 \%$ of records have moderate quality on the dimensions of diagnosis as a process, $53 \%$ of documents have a reasonable condition on the aspects of diagnosis as a product, $63 \%$ of records have moderate quality on the dimensions of intervention, and $64 \%$ of documents have average quality on the dimensions of output nursing. The results of the nursing process that have been obtained in this study illustrate the change or improvement in the improvement of symptoms that have a moderate quality to integrate with the nursing process.
\end{abstract}

Keywords: Diagnosis, Documentation, Intervention, Output 


\section{PENDAHULUAN}

Keperawatan merupakan profesi unik yang memiliki fokus utama caring, yaitu bagaimana memberikan dan mengelola asuhan yang dibutuhkan pasien. Hal ini menjadikan perawat memiliki peran baik pemberi asuhan sebagai kemampuan klinis dan juga koordinator sebagai komponen manajerial. Peran perawat sebagai pemberi asuhan merupakan komponen penting yang esensial dalam sistem pemberian pelayanan kesehatan. Kemampuan dan keterampilan perawat yang kuat dalam kepemimpinan dan administratif sangat penting bagi pasien dan keselamatannya serta sistem layanan dan aksesnya. Mutu asuhan yang unggul dapat memenuhi kebutuhan masyarakat terhadap kesehatan. Tuntutan tersebut membuat perawat perlu dipersiapkan dengan baik untuk membuat dan memelopori strategi perubahan dan mengelola secara efektif koordinasi dan integrasi dari tim interdisipliner, kebutuhan masyarakat, dan sistem asuhan yang berkelanjutan (Rabelo et al., 2016). Itulah sebabnya, integrasi asuhan keperawatan dan manajemen keperawatan menjadi salah satu inti kompetensi yang dibutuhkan perawat untuk menjalankan peran dan fungsinya dalam lingkungan layanan asuhan kesehatan.

Asuhan keperawatan merupakan proses sistematis, terstruktur, dan integratif dalam badan keilmuan keperawatan. Asuhan ini diberikan melalui metode yang disebut proses keperawatan. Proses keperawatan yang didasari teori Orlando Deliberative Nursing Process ini menyatakan bahwa tindakan atau perilaku yang ditunjukkan perawat merupakan hasil pertimbangan berdasarkan kebutuhan pasien. Hal tersebut berarti bahwa perawat profesional melakukan eksplorasi kebutuhan dan masalah atau gangguan kebutuhan yang terjadi pada pasien dengan menggunakan persepsi, proses berpikir kritis, penalaran klinis, dan atau perasaan perawat yang berhubungan dengan kebutuhan dasar pasien. Proses keperawatan membantu perawat mendapatkan luaran, mengukur kualitas pelaksanaan asuhan keperawatan dan memudahkan perawat untuk melakukan praktik klinis keperawatan khususnya bagi perawat pemula (Xiao et al., 2017). Proses keperawatan terdiri dari lima tahapan, yaitu pengkajian, diagnosis, perencanaan, implementasi, dan evaluasi.

Proses keperawatan merupakan gambaran dari hubungan antara pasien dan perawat, identitas dan peran profesionalitas perawat, dan pengembangan pengetahuan perawat. Antusiasme perawat dalam menerima tantangan baru dalam memberikan pelayanan telenursing sangat tinggi, hal tersebut dapat berdampak pada kemampuan meningkatkan komunikasi yang efektif antara perawat dan pasien (Padila et al., 2018). Hubungan antara pasien dan perawat merupakan interaksi timbal balik dimana respon pasien dan perawat saling memengaruhi dan terus berkembang sejalan dengan perubahan respon antara pasien dan perawat. Salah satu fungsi profesionalitas perawat adalah menemukan kebutuhan pasien yang tidak terpenuhi dan kemudian memberikan bantuan untuk memenuhi kebutuhan tersebut. Proses keperawatan memfasilitasi perawat untuk berkembang sebagai seorang pemikir yang logis untuk menghasilkan peningkatan respon dan perilaku pasien dalam pemenuhan kebutuhannya serta pentingnya partisipasi pasien dalam keseluruhan proses (Stonehouse, 2017).

Diagnosis keperawatan merupakan sebuah konsep kritis untuk memandu proses pengkajian dan intervensi (Rabelo et al., 2016). Diagnosis juga menjadi komunikasi dan basis ilmu keperawatan dalam interaksinya dengan disiplin ilmu lain. Diagnosis keperawatan merupakan penilaian perawat berdasarkan respon pasien secara holistik (bio-psiko-sosio-spiritual) terhadap penyakit atau gangguan kesehatan yang dialaminya. Diagnosis sama pentingnya serta memiliki muatan aspek legal dan etis yang sama dengan diagnosis medis. Oleh karena itu, diagnosis keperawatan merupakan kunci 
perawat dalam membuat rencana asuhan yang diberikan pada pasien yang dikelola.

Proses identifikasi gangguan kebutuhan berdasarkan respon yang didapat dari pasien diperoleh dari proses pengkajian keperawatan dan kemudian dianalisis untuk penarikan kesimpulan atau keputusan klinis dalam bentuk diagnosis keperawatan. Diagnosis keperawatan mendeskripsikan respon manusia (pasien) terhadap adanya masalah atau gangguan potensial atau aktual, sementara diagnosis medis merupakan konsep yang mendeskripsikan proses penyakit atau injuri. North America Nursing Diagnosis Association (NANDA) yang kemudian berkembang menjadi NANDAInternasional (NANDA-I) untuk pengembangan dan penggunaan standarisasi terminologi diagnosis keperawatan untuk meningkatkan status kesehatan secara global. Proses pengembangan terus dilakukan untuk perbaikan diagnosis berdasarkan praktik berbasis bukti untuk menentukan tujuan (outcome) dan intervensi yang akan direncanakan dan diberikan kepada pasien (Herdman \& Kamitsuru, 2018). Semakin pendeknya interval diagnosis NANDA-I pada kedua edisi terakhir menunjukkan bahwa perawat perlu lebih sering memperbaharui profesionalitasnya dalam konteks proses keperawatan mengikuti standarisasi yang ada.

Penetapan luaran atau outcome mengarahkan perawat tetap fokus terhadap masalah yang dialami pasien dan menetapkan indikator pencapaian yang kemudian akan menjadi evaluasi perkembangan respon pasien terhadap intervensi yang diberikan perawat. Setiap indikator dibuat terukur untuk memudahkan evaluasi. Oleh karena itu, pendekatan Nursing Outcome Classification (NOC) dan Nursing Intervention Classification (NIC) dapat menjadi panduan perawat dalam menyusun perencanan yang terfokus, sistematis, dan terstruktur dalam proses keperawatan khususnya penetapan tujuan, indikator pencapaian, dan perencanaan intervensi. Muryani et al., (2019) mengungkapkan bahwa seluruh pengkajian keperawatan terdokumentasi tidak sesuai dengan standar (100\%).

Dalam hal ini perawat belum menerapkan standar asuhan yang terdokumentasi sebagai aspek legal dalam pelayanan keperawatan. Namun, dari penelitian sebelumnya belum memaparkan aspek kualitas dokumentasi asuhan keperawatan secara deskriptif untuk memberikan gambaran jelas aspek mana dari proses keperawatan yang sering kali penerapannya tidak sesuai dengan standar yang ada. Selain itu, dirasa perlu mengukur gambaran aplikasi standar berdasarkan standar yang dikeluarkan oleh organisasi profesi sebagai acuan dalam penetapan standar asuhan keperawatan di Indonesia.

\section{METODE PENELITIAN}

Penelitian ini dilakukan di sebuah rumah sakit swasta di Kota Palembang dan proses pengambilan data dilakukan dalam kurun waktu Agustus-Oktober 2019. Sampel yang digunakan sebanyak 105 dokumen dari pasien rawat inap yang proses keperawatannya dianalisis secara random dalam kurun waktu 3 bulan tersebut. Alat ukur yang digunakan dalam penelitian ini adalah Quality of documentation of Nursing Diagnosis, Intervention, and Outcome (Q-DIO). Q-DIO memiliki 29 butir dan empat dimensi yaitu nursing diagnosis as process yang terdiri dari 11 butir, nursing diagnosis as Products yang terdiri dari delapan butir, nursing intervention yang terdiri dari tiga butir, dan nursing-sensitive patient outcomes yang terdiri dari tujuh butir. Skor dari tiap dimensi kemudian dianalisis sebaran datanya menggunakan kuartil untuk klasifikasi kualitas tiap dimensi, sehingga didapatkan kualitas rendah $(<\mathrm{Q} 1)$, kualitas sedang $(\mathrm{Q} 1$ Q3), dan kualitas tinggi (>Q3). 


\section{HASIL PENELITIAN}

Diagnosis Keperawatan sebagai proses menitikberatkan pada aspek pengkajian dan pengumpulan data untuk mendiagnosis masalah keperawatan pasien berdasarkan apa yang dikeluhkan, hasil pengamatan dari pemeriksaan fisik pasien, dan pemeriksaan penunjang seperti laboratorium dan radiologi.

Tabel. 1

Distribusi Frekuensi Tiap Skoring pada Dimensi Diagnosis Keperawatan sebagai Proses $(n=105)$

\begin{tabular}{|c|c|c|c|c|}
\hline & \multirow{2}{*}{ Pengkajian } & \multicolumn{3}{|c|}{ Distribusi tiap skoring [f $(\%)]$} \\
\hline & & 0 & 1 & 2 \\
\hline 1. & $\begin{array}{l}\text { Situasi aktual/nyata yang mendukung dilakukan rawat } \\
\text { inap }\end{array}$ & $2(1,9)$ & 20 (19) & $83(79)$ \\
\hline 2. & $\begin{array}{l}\text { Kecemasan/kekhawatiran yang terkait dengan rawat inap } \\
\text { harapan dan keinginan pada saat rawat inap }\end{array}$ &, $38(36,2)$ & $60(57,1)$ & $7(6,7)$ \\
\hline 3. & Situasi sosial dan lingkungan / lingkungan hidup & $20(19)$ & $68(64,8)$ & $17(16,2)$ \\
\hline 4. & $\begin{array}{l}\text { Koping menghadapi situasi yang nyata yang } \\
\text { dihadapi /dengan penyakit }\end{array}$ & $67(63,8)$ & $36(34,3)$ & $2(1,9)$ \\
\hline 5. & $\begin{array}{l}\text { Keyakinan dan sikap tentang kehidupan (terkait dengan } \\
\text { rawat inap) }\end{array}$ & $27(25,7)$ & $75(71,4)$ & $3(2,9)$ \\
\hline 6. & $\begin{array}{l}\text { Informasi tentang pasien dan kerabat / orang lain yang } \\
\text { berkaitan dengan kondisi pasien }\end{array}$ & $20(19)$ & $15(14,3)$ & $70(66,7)$ \\
\hline 7. & Penerimaan diri sebagai perempuan / laki-laki & $103(98,1)$ & 0 & $2(1,9)$ \\
\hline 8. & Hobi, kegiatan untuk bersantai yang dilakukan & $100(95,2)$ & 0 & $5(4,8)$ \\
\hline 9. & Orang lain yang signifikan (contact person) & $25(23,8)$ & $23(21,9)$ & $57(54,3)$ \\
\hline 10. & Aktivitas sehari-hari & $20(19)$ & $48(45,7)$ & $37(35,2)$ \\
\hline 11. & $\begin{array}{l}\text { Prioritas keperawatan yang relevan berdasarkan } \\
\text { Pengkajian }\end{array}$ & $50(47,6)$ & $25(23,8)$ & $30(28,6)$ \\
\hline
\end{tabular}

Berdasarkan tabel 1 menunjukkan bahwa sebagian besar dokumentasi keperawatan telah terdokumentasi dengan lengkap (skor 2) pada aspek adanya situasi aktual/nyata yang mendukung dilakukannya rawat inap sebanyak 83 dokumen (79\%), informasi tentang pasien dan kerabat/orang lain yang berkaitan dengan kondisi pasien sebanyak 70 dokumen $(66,7 \%)$, dan mengenai contact person sebanyak 57 dokumen $(54,3 \%)$. Selain itu, sebagian besar dokumentasi juga telah terdokumentasi sebagian (skor 1) pada aspek kecemasan terkait rawat inap, harapan, dan keinginan saat rawat inap sebanyak 60 dokumen $(57,1 \%)$, situasi sosial dan lingkungan sebanyak 68 dokumen $(64,8 \%)$, keyakinan dan sikap tentang kehidupan terkait rawat inap sebanyak 75 dokumen (71,4\%), dan mengenai aspek aktivitas sehari-hari sebanyak 48 dokumen $(45,7 \%)$. Sedangkan, empat aspek lainnya menunjukkan sebagian besar tidak terdokumentasi dengan baik.

Tabel. 2

Analisis Univariat Dimensi Diagnosis Keperawatan sebagai Proses $(n=105)$

\begin{tabular}{cclc}
\hline Ukuran Pemusatan & \multicolumn{3}{c}{ Dispersi } \\
\hline \multirow{3}{*}{ Median } & 9,44 & Minimum - maksimum & $0-14$ \\
& 11 & r deviasi & 3,461 \\
& 12 & & $6 ; 11 ; 12$ \\
\hline
\end{tabular}


Berdasarkan tabel 2 menunjukkan bahwa ukuran pemusatan dan dispersi data dimensi diagnosis keperawatan sebagai proses terdistribusi tidak normal. Hal ini juga didukung oleh hasil uji Kolmogorov-Smirnov yang menunjukkan data tidak terdistribusi normal $(\mathrm{p}=0,000)$. Oleh karena itu, distribusi data kemudian dikategorikan dengan $c u t$ of point nilai kuartil dengan kriteria kurang baik jika $\mathrm{X}<\mathrm{Q} 1$, sedang $\mathrm{Q} 1 \leq \mathrm{X} \leq \mathrm{Q} 3$, dan baik jika $X>Q 3$, sehingga diperoleh hasil distribusi seperti pada tabel 3.

Tabel. 3

Distribusi Kategori Dimensi Diagnosis Keperawatan sebagai Proses $(n=105)$

\begin{tabular}{lcc}
\hline \multicolumn{1}{c}{ Kategori } & Frekuensi & Persentase \\
\hline Kurang baik $(<6)$ & 20 & 19 \\
Sedang $(6-12)$ & 70 & 67 \\
Baik $(>12)$ & 15 & 14 \\
\hline
\end{tabular}

Berdasarkan tabel 3 menunjukkan sebagian besar dokumentasi dimensi diagnosis keperawatan sebagai proses memiliki kriteria sedang sebanyak 70 dokumen (67\%), namun ada dokumen yang terdokumentasi kurang baik sebanyak 20 dokumen (19\%), dan juga terdokumentasi baik sebanyak 15 dokumen (14\%).

\section{Diagnosis Keperawatan sebagai Produk}

Diagnosis Keperawatan sebagai produk menitikberatkan pada perumusan diagnosis pasien berdasarkan masalah dan indikator diagnostik keperawatan.

Tabel. 4

Distribusi Frekuensi Tiap Skoring pada Dimensi Diagnosis Keperawatan sebagai Produk $(n=105)$

\begin{tabular}{llllll}
\hline \multicolumn{1}{c}{ Diagnosis Keperawatan } & \multicolumn{5}{c}{ Distribusi tiap skoring [f $(\%)]$} \\
\cline { 2 - 5 } & \multicolumn{1}{c}{0} & \multicolumn{1}{c}{1} & \multicolumn{1}{c}{3} & \multicolumn{1}{c}{4} \\
\hline 1. Masalah/Diagnosa keperawatan / Label & 13 & 3 & 7 & 11 & 70 \\
diagnosis keperawatan didokumentasikan & $(13,3)$ & $(2,9)$ & $(6,7)$ & $(10,5)$ & $(66,7)$ \\
2. Label diagnosis keperawatan & 22 & 11 & 3 & 6 & 63 \\
diformulasikan menurut NANDA dan diberi & $(21)$ & $(10,5)$ & $(2,9)$ & $(5,7)$ & $(60)$ \\
nomor & & & & & \\
3. Etiologi (E) didokumentasikan & 12 & 18 & 9 & 4 & 62 \\
& $(11,4)$ & $(17,1)$ & $(8,6)$ & $(3,8)$ & $(59)$ \\
4. Etiologi (E) benar, sesuai dengan diagnosis & 14 & 30 & 6 & 7 & 48 \\
keperawatan (P) & $(13,3)$ & $(28,6)$ & $(5,7)$ & $(6,7)$ & $(45,7)$ \\
5. Tanda dan gejala dirumuskan & 13 & 11 & 11 & 16 & 54 \\
& $(12,4)$ & $(10,5)$ & $(10,5)$ & $(15,2)$ & $(51,4)$ \\
6. Tanda dan gejala (S) benar berhubungan & 13 & 18 & 8 & 38 & 28 \\
$\quad$ dengan diagnosis keperawatan (P) & $(12,4)$ & $(17,1)$ & $(7,6)$ & $(36,2)$ & $(26,7)$ \\
7. Tujuan keperawatan sesuai dengan diagnosis & 6 & 15 & 8 & 20 & 56 \\
keperawatan & $(5,7)$ & $(14,3)$ & $(7,6)$ & $(19)$ & $(53,3)$ \\
8. Tujuan keperawatan dicapai melalui intervensi & 5 & 18 & 11 & 34 & 37 \\
$\quad$ / tindakan keperawatan & $(4,8)$ & $(17,1)$ & $(10,5)$ & $(32,4)$ & $(35,2)$ \\
\hline
\end{tabular}

Berdasarkan tabel 4 menunjukkan bahwa sebagian besar dokumentasi keperawatan telah terdokumentasi dengan lengkap dan tepat (skor 4) pada aspek adanya masalah keperawatan sebanyak 70 dokumen $(66,7 \%)$, rumusan label diagnosis sesuai NANDA-I sebanyak 63 dokumen (60\%), tiap diagnosis memiliki etiologi yang 
terdokumentasi sebanyak 62 dokumen (59\%), etiologi benar sesuai dengan diagnosis yang ditegakkan sebanyak 48 dokumen $(45,7 \%)$, tanda dan gejala telah dirumuskan sebanyak 54 dokumen $(51,4 \%)$, tujuan keperawatan sesuai dengan diagnosis sebanyak 56 dokumen $(53,3 \%)$, dan intervensi yang direncanakan dapat mencapai tujuan yang ditetapkan sebanyak 37 dokumen $(35,2 \%)$. Selain itu, sebagian besar dokumentasi juga telah terdokumentasi namun sebagian tepat (skor 3) tanda gejala benar sehubungan dengan diagnosis sebanyak 38 dokumen $(36,2 \%)$.

Tabel. 5

Analisis Univariat Dimensi Diagnosis Keperawatan sebagai Produk $(n=105)$

\begin{tabular}{llll}
\hline \multicolumn{1}{c}{ Ukuran Pemusatan } & \multicolumn{2}{c}{ Dispersi } \\
\hline Mean & 22,19 & Minimum - maksimum & $1-32$ \\
Median & 28 & Standar deviasi & 10,081 \\
Modus & 31 & Kuartil & 11,$5 ; 28 ; 30$ \\
\hline
\end{tabular}

Berdasarkan tabel 5 menunjukkan bahwa ukuran pemusatan dan dispersi data dimensi diagnosis keperawatan sebagai proses terdistribusi tidak normal. Hal ini juga didukung oleh hasil uji Kolmogorov-Smirnov yang menunjukkan data tidak terdistribusi normal $(\mathrm{p}=0,000)$. Oleh karena itu, distribusi data kemudian dikategorikan dengan $c u t$ of point nilai kuartil dengan kriteria kurang baik jika $\mathrm{X}<\mathrm{Q} 1$, sedang $\mathrm{Q} 1 \leq \mathrm{X} \leq \mathrm{Q} 3$, dan baik jika $X>Q 3$, sehingga diperoleh hasil distribusi seperti pada tabel 6.

Tabel. 6

Distribusi Kategori Dimensi Diagnosis Keperawatan sebagai Produk $(n=105)$

\begin{tabular}{lll}
\hline Kategori & Frekuensi & Persentase \\
\hline Kurang baik $(<11,5)$ & 26 & 25 \\
Sedang $(11,5-30)$ & 56 & 53 \\
Baik $(>30)$ & 23 & 22 \\
\hline
\end{tabular}

Berdasarkan tabel 6 menunjukkan sebagian besar dokumentasi dimensi diagnosis keperawatan sebagai proses memiliki kriteria sedang sebanyak 56 dokumen (53\%), namun ada dokumen yang terdokumentasi kurang baik sebanyak 26 dokumen (25\%), dan juga terdokumentasi baik sebanyak 23 dokumen (22\%).

\section{Intervensi dan Implementasi Keperawatan}

Intervensi dan Implementasi Keperawatan menitikberatkan pada bagaimana proses perencanaan intervensi yang berisi aktivitas yang akan dilakukan perawat kepada pasien serta pencatatan tindakan yang telah dilakukan kepada pasien dan respon pasien terhadap tindakan yang diberikan. 
Tabel. 7

Distribusi Frekuensi Tiap Skoring pada

Dimensi Intervensi Keperawatan $(\mathrm{n}=105)$

\begin{tabular}{|c|c|c|c|c|c|c|}
\hline \multirow{2}{*}{\multicolumn{2}{|c|}{ Intervensi Keperawatan }} & \multicolumn{5}{|c|}{ Distribusi tiap skoring [f (\%)] } \\
\hline & & 0 & 1 & 2 & 3 & 4 \\
\hline 1 . & $\begin{array}{l}\text { Konkrit/Aktual/Nyata/jelas dan diberi nama } \\
\text { intervensi keperawatan menurut NIC (apa yang } \\
\text { akan dilakukan, bagaimana melakukan, } \\
\text { seberapa sering, } \\
\text { siapa yang melakukannya) }\end{array}$ & $\begin{array}{l}6 \\
(5,7)\end{array}$ & $\begin{array}{l}9 \\
(8,6)\end{array}$ & $\begin{array}{l}23 \\
(21,9)\end{array}$ & $\begin{array}{l}51 \\
(48,6)\end{array}$ & $\begin{array}{l}16 \\
(15,2)\end{array}$ \\
\hline 2. & $\begin{array}{l}\text { Intervensi keperawatan mengatasi } \\
\text { etiologi diagnosis keperawatan }\end{array}$ & $\begin{array}{l}7 \\
(6,7)\end{array}$ & $\begin{array}{l}24 \\
(22,9)\end{array}$ & $\begin{array}{l}22 \\
(21)\end{array}$ & $\begin{array}{l}17 \\
(16,2)\end{array}$ & $\begin{array}{l}35 \\
(33,3)\end{array}$ \\
\hline 3. & $\begin{array}{l}\text { Intervensi keperawatan yang dilakukan, } \\
\text { didokumentasikan (apa yang telah dilakukan, } \\
\text { bagaimana, seberapa sering, } \\
\text { siapa yang melakukannya) }\end{array}$ & $\begin{array}{l}10 \\
(9,5)\end{array}$ & $\begin{array}{l}7 \\
(6,7)\end{array}$ & $\begin{array}{l}30 \\
(28,6)\end{array}$ & $\begin{array}{l}39 \\
(37,1)\end{array}$ & $\begin{array}{l}19 \\
(18,1)\end{array}$ \\
\hline
\end{tabular}

Berdasarkan tabel 7 menunjukkan bahwa sebagian besar dokumentasi keperawatan telah terdokumentasi dengan lengkap dan tepat (skor 4) pada aspek intervensi yang direncanakan mampu mengatasi etiologi diagnosis sebanyak 35 dokumen $(33,3 \%)$. Selain itu, sebagian besar dokumentasi juga telah terdokumentasi namun sebagian tepat (skor 3) pada aspek intervensi yang direncanakan konkrit/aktual/nyata/jelas sesuai NIC serta mengandung apa yang akan dilakukan, bagaimana, seberapa sering, dan siapa yang melakukannya sebanyak 51 dokumen $(48,6 \%)$; dan pada aspek intervensi yang telah dilakukan didokumentasikan dengan lengkap sebanyak $39(37,1 \%)$.

Tabel. 8

Analisis Univariat Dimensi

Intervensi Keperawatan $(n=105)$

\begin{tabular}{llll}
\hline \multicolumn{2}{c}{ Ukuran Pemusatan } & \multicolumn{2}{c}{ Dispersi } \\
\hline Mean & 7,53 & Minimum - maksimum & $0-12$ \\
Median & 8 & Standar deviasi & 3,082 \\
Modus & 10 & Kuartil & 5,$5 ; 8 ; 10$ \\
\hline
\end{tabular}

Berdasarkan tabel 8 menunjukkan bahwa ukuran pemusatan dan dispersi data dimensi diagnosis keperawatan sebagai proses terdistribusi tidak normal. Hal ini juga didukung oleh hasil uji Kolmogorov-Smirnov yang menunjukkan data tidak terdistribusi normal $(\mathrm{p}=0,000)$. Oleh karena itu, distribusi data kemudian dikategorikan dengan cut of point nilai kuartil dengan kriteria kurang baik jika $\mathrm{X}<\mathrm{Q} 1$, sedang $\mathrm{Q} 1 \leq \mathrm{X} \leq \mathrm{Q} 3$, dan baik jika X > Q3, sehingga diperoleh hasil distribusi seperti pada tabel 9.

Tabel 9

Distribusi Kategori Dimensi

Intervensi Keperawatan $(\mathrm{n}=105)$

\begin{tabular}{lll}
\hline Kategori & Frekuensi & Persentase \\
\hline Kurang baik $(<5,5)$ & 26 & 25 \\
Sedang $(5,5-10)$ & 66 & 63 \\
Baik $(>10)$ & 13 & 12 \\
\hline
\end{tabular}


Berdasarkan tabel 9 menunjukkan sebagian besar dokumentasi dimensi diagnosis keperawatan sebagai proses memiliki kriteria sedang sebanyak 66 dokumen (63\%), namun ada dokumen yang terdokumentasi kurang baik sebanyak 26 dokumen (25\%), dan juga terdokumentasi baik sebanyak 13 dokumen (12\%).

\section{Luaran dan Evaluasi Keperawatan}

Luaran Keperawatan menitikberatkan pada penetapan tujuan dan indikator/kriteria hasil yang diharapkan serta evaluasi pencapaian luaran tersebut berdasarkan respon pasien setelah diberikan implementasi keperawatan.

Tabel. 10

Distribusi Frekuensi Tiap Skoring pada Dimensi Luaran/Tujuan Keperawatan $(n=105)$

\begin{tabular}{|c|c|c|c|c|c|c|}
\hline & \multirow{2}{*}{ Luaran/Tujuan Perawatan } & \multicolumn{5}{|c|}{ Distribusi tiap skoring [f $(\%)]$} \\
\hline & & 0 & 1 & 2 & 3 & 4 \\
\hline 1. & $\begin{array}{l}\text { Diagnosis utama/penting, dirubah dan } \\
\text { dinilai setiap hari/setiap shift/bertahan lama dan } \\
\text { dinilai setiap hari keempat. }\end{array}$ & $\begin{array}{l}27 \\
(25,7)\end{array}$ & $\begin{array}{l}8 \\
(7,6)\end{array}$ & $\begin{array}{l}20 \\
(19)\end{array}$ & $\begin{array}{l}4 \\
(3,8)\end{array}$ & $\begin{array}{l}46 \\
(43,8)\end{array}$ \\
\hline 2. & Diagnosis keperawatan dirumuskan kembali & $\begin{array}{l}24 \\
(22,9)\end{array}$ & $\begin{array}{l}2 \\
(1,9)\end{array}$ & $\begin{array}{l}11 \\
(10,5)\end{array}$ & $\begin{array}{l}9 \\
(8,6)\end{array}$ & $\begin{array}{l}59 \\
(56,2)\end{array}$ \\
\hline 3. & Hasil keperawatan didokumentasikan & $\begin{array}{l}12 \\
(11,4)\end{array}$ & $\begin{array}{l}9 \\
(8,6)\end{array}$ & $\begin{array}{l}14 \\
(13,3)\end{array}$ & $\begin{array}{l}11 \\
(10,5)\end{array}$ & $\begin{array}{l}59 \\
(56,2)\end{array}$ \\
\hline 4. & $\begin{array}{l}\text { Hasil/tujuan keperawatan hasilnya bisa } \\
\text { diamati/terukur dan didokumentasikan menurut } \\
\text { NOC }\end{array}$ & $\begin{array}{l}11 \\
(10,5)\end{array}$ & $\begin{array}{l}21 \\
(20)\end{array}$ & $\begin{array}{l}6 \\
(5,7)\end{array}$ & $\begin{array}{l}27 \\
(25,7)\end{array}$ & $\begin{array}{l}40 \\
(38,1)\end{array}$ \\
\hline 5 . & $\begin{array}{l}\text { Hasil keperawatan menunjukkan: Peningkatan gejala } \\
\text { pasien, Peningkatan status pengetahuan pasien, } \\
\text { Peningkatan strategi koping pasien, Peningkatan } \\
\text { kemampuan perawatan diri, Peningkatan status } \\
\text { fungsional }\end{array}$ & $\begin{array}{l}16 \\
(15,2)\end{array}$ & $\begin{array}{l}17 \\
(16,2)\end{array}$ & $\begin{array}{l}8 \\
(7,6)\end{array}$ & $\begin{array}{l}15 \\
(14,3)\end{array}$ & $\begin{array}{l}49 \\
(46,7)\end{array}$ \\
\hline 6. & $\begin{array}{l}\text { Ada hubungan antara outcome keperawatan } \\
\text { dengan intervensi keperawatan }\end{array}$ & $\begin{array}{l}5 \\
(4,8)\end{array}$ & $\begin{array}{l}27 \\
(25,7)\end{array}$ & $\begin{array}{l}4 \\
(3,8)\end{array}$ & $\begin{array}{l}42 \\
(40)\end{array}$ & $\begin{array}{l}27 \\
(25,7)\end{array}$ \\
\hline 7. & $\begin{array}{l}\text { Hasil keperawatan dengan diagnosis } \\
\text { keperawatan terkait secara integral }\end{array}$ & $\begin{array}{l}6 \\
(5,7)\end{array}$ & $\begin{array}{l}26 \\
(24,8)\end{array}$ & $\begin{array}{l}2 \\
(1,9)\end{array}$ & $\begin{array}{l}16 \\
(15,2)\end{array}$ & $\begin{array}{l}55 \\
(52,4)\end{array}$ \\
\hline
\end{tabular}

Berdasarkan tabel 10 menunjukkan bahwa sebagian besar dokumentasi keperawatan telah terdokumentasi dengan lengkap (skor 4) pada seluruh aspek dengan frekuensi masing-masing aspek sebanyak 46 dokumen (43,8\%), 59 dokumen $(56,2 \%), 59$ dokumen $(56,2 \%), 40$ dokumen $(38,1 \%), 49$ dokumen $(46,7 \%)$, dan 27 dokumen $(25,7 \%)$.

Tabel. 11

Analisis Univariat Dimensi

Luaran/Tujuan Keperawatan $(n=105)$

\begin{tabular}{llll}
\hline \multicolumn{3}{c}{ Ukuran Pemusatan } & \multicolumn{2}{c}{ Dispersi } \\
\hline Mean & 18,59 & Minimum - maksimum & $0-28$ \\
Median & 24 & Standar deviasi & 9,609 \\
Modus & 25 & Kuartil & $7 ; 24 ; 26$ \\
\hline
\end{tabular}


Berdasarkan tabel 11 menunjukkan bahwa ukuran pemusatan dan dispersi data dimensi diagnosis keperawatan sebagai proses terdistribusi tidak normal. Hal ini juga didukung oleh hasil uji Kolmogorov-Smirnov yang menunjukkan data tidak terdistribusi normal $(\mathrm{p}=0,000)$. Oleh karena itu, distribusi data kemudian dikategorikan dengan cut of point nilai kuartil dengan kriteria kurang baik jika $\mathrm{X}<\mathrm{Q}$, sedang $\mathrm{Q} 1 \leq \mathrm{X} \leq \mathrm{Q} 3$, dan baik jika $X>Q 3$, sehingga diperoleh hasil distribusi seperti pada tabel 12 .

Tabel. 12

Distribusi Kategori Dimensi

Luaran/Tujuan Keperawatan $(n=105)$

\begin{tabular}{lll}
\hline Kategori & Frekuensi & Persentase \\
\hline Kurang baik $(<7)$ & 22 & 21 \\
Sedang $(7-26)$ & 67 & 64 \\
Baik $(>26)$ & 16 & 15 \\
\hline
\end{tabular}

Berdasarkan tabel 12 menunjukkan sebagian besar dokumentasi dimensi luaran keperawatan memiliki kriteria sedang sebanyak 67 dokumen (64\%), namun ada dokumen yang terdokumentasi kurang baik sebanyak 22 dokumen (21\%), dan juga terdokumentasi baik sebanyak 16 dokumen (15\%).

\section{PEMBAHASAN}

Kualitas asuhan yang berfokus pada tampilan kinerja keperawatan melalui proses keperawatan merupakan sebuah indikator yang penting dan dapat diukur dari dokumentasi keperawatan (Xiao et al., 2017). Sejarah fokus dokumentasi keperawatan sebelumnya berorientasi pada dokumentasi proses keperawatan yang komprehensif dan kemudian berkembang menjadi diagnosis keperawatan yang lengkap namun belum memerhatikan kualitas dari dokumentasi diagnosis keperawatan, intervensi, dan luaran. Hubungan yang logis, berdasarkan teori, dan koheren antara diagnosis, luaran pasien, dan intervensi keperawatan menjadi penekanan yang penting, bahkan diagnosis keperawatan menjadi tidak berfungsi tanpa adanya kaitan dengan luaran dan intervensi. Luaran keperawatan menjadi "jembatan" untuk menstandarisasi hubungan antara diagnosis dengan intervensi. Sedangkan, intervensi keperawatan dinilai untuk mengevaluasi efek intervensi terhadap diagnosis. Diagnosis keperawatan berfungsi untuk meningkatkan kualitas pengkajian yang dilakukan dan didokumentasikan oleh perawat. Diagnosis keperawatan sebagai proses terkait pada kajian deskripsi masalah pasien, penyebabnya, dan dapat memberikan informasi kepada perawat untuk mengidentifikasi pendekatan kajian apa yang sesuai untuk membuat perencanaan spesifik terkait diagnosis keperawatan pasien. Sehingga, secara tidak langsung akan membuat pengkajian perawat lebih komprehensif dan spesifik berorientasi pada masalah dan diagnosis pasien.

Situasi aktual atau nyata yang mendukung dilakukannya rawat inap pada pasien umumnya didapatkan dari keluhan utama pasien secara spesifik yang mengakibatkan pasien mencari layanan perawatan dan biasanya berhubungan dengan penyakitnya. Namun ada persepsi bahwa keluhan utama adalah keluhan yang pasien sampaikan secara subyektif pada saat interaksi pertama kali, padahal tidak semua yang dikeluhkan pasien saat pertama kali berinteraksi dengan perawat merupakan alasan pasien datang ke layanan kesehatan tetapi apa yang pasien rasakan pada saat ditanya oleh perawat. Kalimat pertanyaan "Apa keluhannya Pak/Bu?" atau "Apa yang dirasakan Pak/Bu?" 
sebenarnya belum spesifik bertujuan menggali alasan pasien mencari layanan kesehatan, dan ambigu dengan beda interpretasi seperti "apa yang dirasakan saat ini (saat ditanya)" alih-alih "kenapa datang ke rumah sakit". Oleh karena itu, perlu ada kajian yang lebih dalam (in-depth interview) hingga tergali etiologi dasar dari masalah kesehatan pasien, dan yang didokumentasikan adalah tanda gejala yang dirasakan pasien.

Hasil temuan penelitian ini pada salah satu dokumentasi keluhan utama pasien adalah "mual". Data tersebut akan lebih baik jika didokumentasikan dengan lebih spesifik mengarah pada kondisi hipertensi seperti "mual yang disertai dengan pusing". Dokumentasi pengkajian "mual" akan mengarahkan analisis proses diagnosis menjadi Diagnosis Keperawatan Mual/Nausea (Herdman, Kamitsuru, 2018). Diagnosis tersebut sesuai dengan proses penegakkan diagnosis berdasarkan tanda gejala namun akan menjadi tidak tepat jika diagnosis yang ditegakkan hanya satu sehingga Diagnosis Mual menjadi prioritas pertama, seperti yang ditemukan dalam penelitian ini.

Hal inilah yang mengakibatkan prioritas keperawatan menjadi tidak relevan berdasarkan pengkajian. Tetapi, jika pengkajian lebih lanjut dilakukan, maka akan didapatkan bahwa pasien yang mengalami ketidakstabilan tekanan darah dapat mengakibatkan kondisi mual atau muntah, sehingga akan didapatkan Diagnosis Risiko Ketidakstabilan Tekanan Darah. Oleh karena itu, akan pasien kemudian dapat didiagnosis Ketidakstabilan Tekanan Darah dan Mual dengan Diagnosis Risiko Ketidakstabilan Tekanan Darah sebagai prioritas pertama dan diikuti dengan Diagnosis Mual.

Penelitian ini juga menemukan bahwa aspek pengkajian mengenai kecemasan terkait hospitalisasi, kondisi lingkungan sosial dan tempat tinggal, mekanisme koping, keyakinan terkait hospitalisasi, penerimaan diri, dan hobi tidak didukung oleh sistem informasi keperawatan yang digunakan pada lokasi penelitian karena bersifat check-list dan isian singkat. Aktivitas sehari-hari yang dapat didokumentasikan terkait aktivitas sebelum dan sesudah sakit untuk membandingkan aktivitas yang masih dan sudah tidak dapat dilakukan lagi oleh pasien. Sedangkan contact person yang didokumentasikan adalah penanggung jawab pasien yang biasanya merupakan anggota keluarga pasien. Hal ini yang dikeluhkan oleh perawat sehingga mengakibatkan dokumentasi keperawatan tidak mencantumkan data yang spesifik.

Kategori dokumentasi pengkajian (berdasarkan distribusi data) sebagian besar dokumen berada pada kategori sedang sebanyak 70 dokumen (67\%). Hal ini menunjukkan selain karena SIM-Kep yang belum mumpuni, secara keseluruhan dokumen khususnya dalam aspek pengkajian sudah mampu menjadi bahan kajian dalam mendiagnosis pasien. Selain itu, dokumen masih memiliki potensi untuk ditingkatkan menjadi dokumentasi yang komprehensif serta berorientasi pada proses berpikir kritis (critical thinking) dan penalaran klinis (clinical reasoning) bagi pendidikan dan penelitian keperawatan secara mutualis (Melin et al., 2017).

Hasil penelitian menunjukkan sebagian besar diagnosis telah terdokumentasi (Tabel 4), namun beberapa diagnosis yang dinilai skor 0-3 karena ketidaktepatan penegakkan diagnosis berdasarkan data yang didapat dari pengkajian serta seluruh diagnosis belum memiliki nomor label sesuai NANDA. Beberapa etiologi diagnosis yang terdokumentasi dinilai belum sesuai dengan kondisi pasien secara spesifik, begitu juga pada aspek tanda dan gejala. Hal ini terjadi karena database dalam SIM-Kep yang digunakan belum menampung seluruh etiologi dan simptom yang terdapat dalam NANDA atau SDKI. Analisis tanda dan gejala merupakan pendukung penegakkan masalah atau etiologi keperawatna, misalnya data kekuatan otot pada pasien stroke. 
Kekuatan otot dapat dikaji dengan menggunakan skala Manual Muscle Test (0-5), skala ini yang akan menjadi patokan untuk melanjutkan proses luaran dan intervensi (Daeli et al., 2018).

Diagnosis yang telah ditegakkan perlu dibuat target luaran guna menyelesaikan masalah keperawatan dengan mengatasi penyebab atau tanda gejalanya, sehingga tujuan yang dibuat harus berdasarkan diagnosis. Tujuan yang telah dibuat tersebut kemudian dianalisis untuk pembuatan rencana intervensi yang diperlukan untuk mencapai tujuan. Sistematika analisis pada proses tersebut menunjukkan pentingnya dan krusialnya diagnosis yang ditegakkan oleh perawat atau sebagai produk/hasil analisis perawat terhadap proses kajian berdasarkan tanda gejala yang dirasakan atau muncul pada pasien. Peran kritis diagnosis akan berdampak pada penetapan tujuan dan perencanaan intervensi yang berorientasi pada penyelesaian masalah keperawatan.

Kategori kualitas sedang pada dimensi diagnosis sebagai produk memiliki separuh dari jumlah sampel, yaitu $53 \%$ dan $22 \%$ dokumen berada pada kategorik kualitas baik. Hal tersebut terjadi karena tiap dokumen memiliki diagnosis keperawatan sesuai NANDA, namun etiologi dan tanda gejala pada tiap diagnosis belum tepat. Hal ini disebabkan karena database SIM-Kep belum berisi seluruh etiologi diagnosis serta belum dapat memverifikasi data abnormal yang menjadi batasan karakteristik tiap diagnosis, sehingga data normal pun muncul dalam tampilan akhir (output) dokumentasi.

Intervensi keperawatan dibuat untuk mencapai tujuan dan kriteria hasil yang diharapkan guna mengatasi etiologi dan menyelesaikan masalah keperawatan. Intervensi dibuat secara spesifik dan operasional yang terdiri dari aktivitas apa yang akan dilakukan, bagaimana, seberapa sering, dan lebih baik lagi jika teridentifikasi siapa yang melakukan. Prinsip tersebut perlu dilakukan supaya tiap perawat yang melihat perencanaan keperawatan mudah untuk melakukannya atau mengaplikasikan rencana tersebut. Setelah tindakan telah dilakukan, tiap intervensi dievaluasi berdasarkan respon pasien terhadap tiap tindakan yang telah diimplementasikan dan mengacu atau berorientasi pada kriteria hasil yang telah ditetapkan (Abdelkader, Othman, 2017).

Dokumen yang dianalisis dalam penelitian ini menunjukkan bahwa intervensi yang telah direncanakan sudah mencakup aspek tindakan observasi,

mandiri, dan kolaborasi. Namun, belum semua berorientasi pada tujuan dan kriteria hasil. Selain itu, spesifikasi intervensi mengenai bagaimana, seberapa sering, dan siapa yang melakukan tindakan belum didukung oleh sistem informasi yang digunakan karena perawat tidak dapat menginput spesifikasi tersebut dalam bentuk isian (Tabel 7).

Prinsip lain yang juga menjadi dasar proses intervensi-implementasi adalah "lakukan apa yang ditulis" (intervensi-implementasi) dan "tulis apa yang dilakukan" (implementasi-dokumentasi). Kedua prinsip tersebut merupakan dasar pendokumentasian/pencatatan dan pelaporan asuhan keperawatan. Prinsip tersebut akan mempertahankan aspek legal dan etik keperawatan serta dapat melindungi perawat dari segi atau aspek hukum dan etik. Pada bahasan diagnosis keperawatan telah dipaparkan satu contoh tentang masalah keperawatan yang didasari oleh tanda dan gejala yakni kekuatan otot pada pasien stroke. Untuk intervensi, perlu dilakukan pemilihan tindakan apa yang dilakukan untuk mengatasi masalah tersebut, salah satu intervensi yang dapat dilakukan untuk dipilih dalam mengatasi kekuatan otot adalah dengan latihan menggenggam (Daeli et al., 2018). Latihan menggenggam merupakan salah satu bagian dari Range of Motion, yang juga dapat digunakan untuk melatih sendi pasien yang mengalami gangguan sehingga dapat berfungsi dengan maksimal sesuai dengan fungsi 
dasarnya (Pranata et al., 2019). Aplikasi dari contoh intervensi yang telah dipaparkan merupakan gambaran penegakkan rencana keperawatan yang akan diimplementasikan pada asuhan keperawatan pasien.

Sebagian besar dokumentasi implementasi yang terdapat dalam dokumen penelitian ini, tidak hanya intervensi yang telah direncanakan tetapi juga banyak di luar intervensi yang dicatat seperti proses serah terima pasien antar shift. Catatan respon pasien terhadap tindakan perawat juga belum berorientasi pada kriteria hasil sehingga sulit untuk menilai apakah implementasi dari intervensi yang direncanakan sudah mencapai tujuan atau belum. Selain itu, waktu (tanggal dan jam) pemberian tindakan atau implementasi sudah tercatat dengan baik. Sehingga secara keseluruhan dokumentasi intervensi dan implementasi keperawatan memiliki kategorik sedang sebanyak 66 dokumen (63\%) (Tabel 9).

Tujuan keperawatan yang terdiri dari waktu, luaran yang diharapkan, status perubahan, serta indikator atau kriteria hasil, harus memenuhi prinsip Specific, Measureable, Achievable, Reliable/Rasional, dan Time (SMART). Hasil pengolahan data menunjukkan sebagian besar dokumen memiliki skor sangat baik (skor 4) untuk seluruh aspeknya (Tabel 10). Indikator tujuan dapat diukur, terdapat keterkaitan antara luaran dengan intervensi keperawatan, diagnosis keperawatan dinilai setiap shift dan dirumuskan kembali. Hasil keperawatan berupa respon pasien setelah dilakukan tindakan/implementasi menggambarkan perubahan atau peningkatan perbaikan gejala pasien saja, namun belum disesuaikan dengan luaran dan diagnosis secara integral.

Luaran yang ditargetkan perawat antara lain perubahan gejala, status fungsional, pengetahuan, strategi koping, dan perawatan diri pasien. Makna dari istilah "nursingsensitive patient outcomes" adalah luaran yang menjadi tanggung jawab perawat untuk mencapainya. Luaran pasien diukur berdasarkan tercapai atau tidaknya tujuan keperawatan dan teratasi atau tidak teratasinya diagnosis keperawatan. Indikator atau kriteria hasil luaran keperawatan memang tidak memiliki patokan khusus, namun dibebaskan berdasarkan proses berpikir kritis dan penalaran klinis perawat (Xiao et al., 2017). Hal ini yang sering menjadi kendala bagi perawat yang baru mengenal dan menggunakan standar $N O C$, namun kendala tersebut dapat dikurangi atau bahkan dihilangkan dengan mengikuti pelatihan (Setyaningrum et al., 2019).

\section{SIMPULAN}

Simpulan pada penelitian ini menunjukkan bahwa sebagian besar dokumen memiliki kualitas sedang pada dimensi diagnosis sebagai proses, sebagian dokumen memiliki kualitas sedang pada dimensi diagnosis sebagai produk, sebagian besar dokumen memiliki kualitas sedang pada dimensi intervensi, dan sebagian besar dokumen memiliki kualitas sedang pada dimensi luaran keperawatan.

\section{SARAN}

SIM-Kep yang digunakan rumah sakit direkomendasikan oleh peneliti untuk dilakukan pembaharuan baik dalam aspek database sesuai dengan standar asuhan keperawatan yang ada (NANDA-I 2018-2020 atau yang terbaru nanti dan SDKI 2017, NOC edisi 6 dan SLKI 2017, serta NIC edisi 6 dan SIKI 2017), dan juga aplikasi sistem yang lebih adaptif sesuai kebutuhan operasional di lapangan. Selain itu, perlu dilakukan workshop atau pelatihan bagi pengguna sistem, baik mengenai aplikasi sistem atau proses keperawatan sesuai standar yang terbaru. 


\section{DAFTAR PUSTAKA}

Abdelkader, F. A., \& Othman, W. N. E. (2017). Factors Affecting Implementation of Nursing Process: Nurses â $€^{\mathrm{TM}}$ Perspective. IOSR Journal of Nursing and Health Science, 6(3), 76-82. https://doi.org/10.9790/1959-0603017682

Daeli, N. E., Suwarno, M. L., \& Budiharto. (2018). Perbedaan Kekuatan Otot Sebelum dan Sesudah Latihan Menggenggam pada Penderita Cerebrovascular Disease (CVD). Jurnal Kesehatan Saelmakers Perdana, 1(1), 38-43. https://doi.org/10.32524/jksp.v1i1.334

Herdman, T. H., \& Kamitsuru, S. (2018). Nursing Diagnosis: Definitions and Classification (11th ed.). Thieme

Melin, J. C., Palmqvist, R., \& Rönnberg, L. (2017). Clinical Intuition in the Nursing Process and Decision-Making - A Mixed Studies Review. Jounal of Clinical Nursing, 26(23-24), 3936-3949. https://doi.org/10.1111/jocn.13814

Muryani, P, E., \& Setiawan, H. (2019). Kualitas Pendokumentasian Asuhan keperawatan di Ruangan Rawat Inap: Studi di RSUD Kalimantan Tengah. Nerspedia, 2(1), 27-32

Padila, P., Lina, L. F., Febriawati, H., Agustina, B., \& Yanuarti, R. (2018). Home Visit Berbasis Sistem Informasi Manajemen Telenursing. Jurnal Keperawatan Silampari, 2(1), 217-235. https://doi.org/10.31539/jks.v2i1.305

Pranata, L., Koerniawan, D., \& Daeli, N. E. (2019). Efektivitas ROM terhadap Gerak Rentang Sendi Lansia. Proceeding Seminar Nasional Keperawatan, 110-117

Rabelo, S. E. R., Cavalcanti, A. C. D., Caldas, M. C. R. G., Lucena, A. de F., Almeida, M. de A., Linch, G. F. da C., da Silva, M. B., \& Muller-Staub, M. (2016). Advanced Nursing Process quality: Comparing the International Classification for Nursing Practice (ICNP) with the NANDA-International (NANDA-I) and Nursing Interventions Classification (NIC). Journal of Clinical N, 26, 379-387. https://doi.org/10.1111/jocn.13387

Setyaningrum, E. E., Nurjannah, I., \& Rustiyaningsih, A. (2019). Effect of NANDA-I, NIC, and NOC Documentation System Training on Quality of Nursing Care Documentation in The Perinatal Ward of Yogyakarta Regional Public Hospital. Belitung Nursing Journal, $\quad$ 5(2), 180-191. https://doi.org/https://doi.org/10.33546/bnj.770

Stonehouse, D. (2017). Understanding the Nursing Process. British Journal of Healthcare Assistants, 11(8), 388-391

Xiao, S., Widger, K., \& Tourangeau, A. (2017). Nursing Process Health Care Indicators: A Scoping Review of Development Methods. Journal of Nursing Care Quality, 32(1), 32-39. https://doi.org/10.1097/NCQ.0000000000000207 